Article

\title{
"Chuck Norris, Please Help!" Transnational Cultural Flows in the 2017 Anti-Corruption Protests in Romania
}

\author{
Delia Dumitrica \\ Media and Communication, Erasmus School of History, Culture and Communication, Erasmus University Rotterdam, \\ The Netherlands; E-Mail: dumitrica@eshcc.eur.nl
}

Submitted: 8 March 2021 | Accepted: 27 May 2021 | Published: 13 September 2021

\begin{abstract}
This study examines the meaning-making work of transnational cultural references in protest. Whether using the image of the superhero or re-mixing a famous painting, the presence of such references in home-made protest placards was a striking feature of the 2017 anti-corruption protests in Romania. By means of a qualitative analysis of 58 such signs, this study identifies five types of transnational cultural resources co-opted in the local protest: politics, high and popular culture, brand names, computer culture, and other motivational slogans and protest symbols. Such references are appropriated in local protest for their recognizability potential, their generic interpretive frames, or their usefulness in generating surprising re-iterations of the political cause. Yet, the use of such references remains interwoven with the symbolic and political capital of professional, middle-class elites. In the Romanian case, the use of these transnational cultural references also constructs the protesters as cosmopolitan and aligned with Western cultural consumption and political practices. In turn, this frames political opponents as backwards, parochial, and unfit for democratic politics.
\end{abstract}

\section{Keywords}

circulation of culture; glocality; hybridity; protest communication; protest visuals; transnational cultural references

Issue

This article is part of the issue “From Sony's Walkman to RuPaul's Drag Race: A Landscape of Contemporary Popular Culture” edited by Tonny Krijnen (Erasmus University Rotterdam, The Netherlands), Frederik Dhaenens (Ghent University, Belgium) and Niall Brennan (Fairfield University, USA).

(C) 2021 by the author; licensee Cogitatio (Lisbon, Portugal). This article is licensed under a Creative Commons Attribution 4.0 International License (CC BY).

\section{Introduction}

This study focuses on the meaning-making work of transnational cultural references in protest. Using data from the 2017 anti-corruption protests in Romania, the study asks how symbolic resources from other geopolitical and cultural contexts become re-used in national protests and how this glocalized meaningmaking work contributes to the mobilization and amplification of protests.

Transnational references such as HBO series, Italian Renaissance paintings, English novels, or North Korean politics, for instance, are reused in homemade protest visuals such as banners, protests placards, or art installations. Protest visuals condense everyday political talk (Graham \& Hajru, 2011), participate in collective iden- tity building, and provide photographic opportunities for media coverage and social media circulation and archiving (Faulkner, 2013; Juris, 2008; Mattoni \& Teune, 2014). Where the transnational diffusion of collective identity and action frames has been studied in relation to social movements (della Porta \& Kriesi, 1999; della Porta \& Mattoni, 2014), there is less attention to how seemingly global cultural references are mobilized in national protest to generate novel expressions of civic dissent. Furthermore, the role of visuals in protest communication remains understudied (Mattoni \& Teune, 2014; Philipps, 2012; Rovisco \& Veneti, 2017). This study draws attention to an underexamined form of the glocalization of protest, and adds to existing examinations of visuals in protests. As such, the study addresses the following empirical questions: Which transnational 
cultural references are mobilized in national protest; and how do these references contribute to local political meaning-making?

\section{The 2017 Anti-Corruption Protests in Romania}

The 2017 \#rezist/OUG13 anti-corruption protests in Romania represent a case of sustained protests against an ongoing political issue endemic to post-communist political systems: the corruption of the political elites (Olteanu \& Beyerle, 2017). Recent activism in Romania has been nationally-oriented, defined by an overarching concern with the effects of communism in the democratic and economic development of the country, and reflective of the pro-European, middle-class ethos (Gubernat \& Rammelt, 2021). A cause of ongoing protest, corruption has been framed by local activists and political commentators as a consequence of communism's "unresolved issues of the past" (Abăseacă, 2018, p. 681), eventually growing into a "quasi-hegemonic metanarrative and identity marker of the urban middle class in Romania" (Kiss \& Székely, 2021, p. 11).

Such national activism also has transnational dimensions. Successive waves of citizen mobilizations since the early 2010s had echoed the mobilizational practices and organizational values of the wider anti-austerity movements. "[D]ecisions made by consensus, the lack of leaders, horizontality, the occupation of public square" (Abăseacă, 2018, p. 681) have also infused the 2017 anti-corruption protests, yet they were appropriated "without including a criticism of neoliberalism and of liberal democracy or showing a sensitivity toward social issues that were important aspects for the post-2011 anti-austerity mobilizations" (Abăseacă, 2018, p. 681). Furthermore, these protests have also been widely supported by expat communities which relied on social media (under the hashtag \#rezist) to create transnational resonance for the national protests (Mercea, 2020). These communities held protests in other countries, drawing international media attention to the situation in Romania while also livecasting the events and sharing protest visuals on the social media accounts of the organizers in Romania.

The 2017 \#rezist protests were fueled by ongoing discontent, largely among the urban young and the middle-class, with the corruption of the political elites represented by the ruling Social Democrat Party (PSD; Gubernat \& Rammelt, 2021; Kiss \& Székely, 2021). The party's president, Liviu Dragnea, had a previous fraud conviction and was under criminal investigation for another act of corruption at the time of the protests. The latter erupted when PSD attempted to pass a legislative package that would have decriminalized acts of corruption under approx. 40,000 euro. This would have effectively exonerated Dragnea in the ongoing investigation against him. In spite of warnings from the Romanian president and other public bodies that such a legislative package would be a step back in the fight against cor- ruption; and, in spite of a demonstration against this package that had just taken place, the government still pushed through with the legal changes by means of an emergency ordinance (also known as OUG13) passed late-night on January 31, 2017.

The press conference that night became a major political blunder. The Justice Minister refused to take any questions about the passing of the emergency ordinance, provoking widespread anger among both journalists and citizens watching from home. Within hours, thousands of people had gathered throughout the entire country (Olteanu \& Beyerle, 2017). In early February, a mass protest brought together over 500,000 people across the country (Mercea, 2020). And, although the emergency ordinance was nullified and the Justice Minister resigned, mass demonstrations continued with some estimates putting them at 150,000 to 200,000 protesters daily (Olteanu \& Beyerle, 2017). Throughout 2017 and 2018, citizens continued to take the streets intermittently in response to the government's renewed attempts to curb the anti-corruption legal and institutional framework.

\section{Transnational Cultural References in Protest Visuals}

This section engages with two dimensions of protest placards: the specifics and functions of visual meaningmaking in protest; and their transnational dimension. These dimensions provide a theoretical framework for the understanding the meaning-making work performed by the transnational cultural references used in the protest signs analyzed here.

\subsection{Visual Objects and Meaning-Making}

Whether taking the form of a text, a photograph, a drawing, an installation, a costume, or combinations thereof, protest signs are objects displayed to be seen by others. This visual dimension complexifies their meaningmaking work. In cases where photographs, drawings, illustrations, or even costumes are used, signification is affected by the "perception of likeness or resemblance or analogous form" (Mitchell, 2015, as cited in Gori, 2016, p. 41). The analysis of such signification work has to consider the process of sensorial recognition and ensuing emotional reactions entailed in visual meaningmaking, as the latter combines "aesthetic familiarity" and "generic meanings" to convey "collectively shared but often inchoate and diffuse sentiments and understandings" (Bartmanski, 2015, p. 17).

Analytically, three layers of meaning-making can be distinguished in visual objects (Panofsky, 1970, as cited in van Leeuwen, 2011). The representational layer elicits an understanding spurred by familiarity with the conventions of the genre, such as the recognition of the overall communicative purposes and of the general traditions of home-made protest signs. Iconographical symbolism resembles the connotative level of signs, drawing attention to the cultural baggage and semantic associations 
of the people or places in an image. Finally, iconological symbolism speaks to the wider ideological message that the visual as a whole seeks to convey. Panofsky explains this layer of analysis as an effort to "ascertain those underlying principles which reveal the basic attitude of a nation, a period, a class, a religious or philosophical persuasion" (Panofsky, 1970, as cited in van Leeuwen, 2011, p. 11).

Some visuals also become iconic, meaning they achieve "wholly exceptional levels of widespread recognizability" (Kemp, 2012, as cited in Hubbert, 2014, p. 115). Iconic visuals emerge as a "dominant symbolic representation of the events" gaining seemingly universal normative undertones such as good/bad (Hubbert, 2014 , p. 115). In such cases, emotional grip, recognizability, and the naturalization of meaning intersect in conveying a message. Iconic visuals in/of protest "reflect social knowledge and dominant ideologies; they shape understanding of specific events and periods; they influence political action by modelling relationships between civic actors; and they provide figural resources for subsequent communicative action" (Hariman \& Lucaites, 2002, p. 366). Furthermore, iconic visuals can potentially be "diffused more easily over cultural, linguistic, ideological and political borders and can have a unifying effect on a public sphere by focusing debates on issues of shared relevance" (Mortensen \& Trenz, 2016, p. 258).

While this makes them powerful means of communicating, amplifying the political values underpinning protests (Olesen, 2014; Rovisco, 2017; Wetzstein, 2017), visuals have also been criticized for their "dumbing-down" potential and propensity towards playing upon the spectacular which may presumably downplay critical thinking and rational engagement with politics (Parry, 2015).

\subsection{Visuals in/of Protest}

Visuals fulfill multiple functions in protest: convey information, document injustice, participate in identitybuilding and mobilization, attract media attention to amplify the cause, and generate debate (Casas \& Williams, 2019; Faulkner, 2013; Mattoni \& Teune, 2014; Milner, 2013; Mortensen \& Trenz, 2016). Prominently displayed by individuals during protest, placards are a form of public voice and a performance of citizenship. Their political message links the individual to the collective by simultaneously conveying the individual's political stance and articulating it with the wider protest cause. In the process of being seen by others, protest signs participate in the generation of collective identities and solidarity among protesters (Vanni, 2007).

Placards also constitute opportunities for protest image generation. In a political world where images proliferate, images in/of protest often struggle to achieve visibility in the public sphere (Rovisco \& Veneti, 2017). Striking protest signs make for great photographic opportunities, while their concise and slogan-like nature pro- vides testimonials for the news reporting of the actual events (Mattoni \& Teune, 2014). In decentralized and digitally mediated protests where individual organizers or leaders can be difficult to identify, this can prove to be particularly useful. Yet, as shown by the protest paradigm literature, media coverage has often foregrounded the spectacular side at the expense of the political demands of protests (McCurdy, 2012).

In today's panmediated political world (De Luca et al., 2012 , p. 500), social media offer protesters new means of circulating and archiving protest visuals that co-exist alongside traditional media (Mattoni \& Teune, 2014; Poell, 2014). Even more so than a journalistic photograph of a protest, images captured by participating citizens convey a sense of spontaneity and authenticity (Wetzstein, 2017, p. 31). Growing online circulation can both attract media's attention to the cause and expand the face-to-face protest by creating a space for social and political discussion (Milner, 2013). Social media chatter and virality can thus boost protest communication, influencing the public agenda without having to rely (exclusively) on the amplification and legitimation brought about by news media coverage, while also extending the lifecycle of a protest beyond the presence of bodies on the streets. Yet, while they may bring in distant, potentially global publics (Mattoni \& Teune, 2014), the "instant news icons" generated through social media chatter and virality can also remain transient (that is, they easily disappear from collective memory) and recognizable only to fragmented publics (Mortensen, 2016).

Finally, handmade protest signs are also tokens of vernacular creativity. Ingenious and playful crafting of political meaning-making often plays upon collective semantic reservoirs and "complex sets of inter-visual relations" (Faulkner, 2013, p. 14). In so doing, they can simultaneously reproduce and transform these semiotic resources. As forms of "vernacular creativity" (Burgess, 2006), protest visuals merge political agency and resistance with belonging, playfulness, and aesthetic innovation. "Vernacular creativity" is thus a "process by which available cultural resources... are recombined in novel ways, so that they are both recognizable because of their familiar elements, and create affective impact through the innovative process of this recombination" (Burgess, 2006, p. 206). By remixing cultural resources to generate new texts and chains of signification, protest placards also enhance the virality of cultural references. Protest visuals can thus simultaneously fulfill several social and communicational functions, working at once as an act of participation and voice, a means of amplification via news coverage and social media virality, a ludic yet political gestures, and a form of cultural production and circulation.

\subsection{The Transnational Circulation of Cultural References}

Protest causes, identities, and repertoires of action travel across national borders (della Porta \& Mattoni, 2014, 
p. 9). Even nationally-oriented protests, such as the case examined here, entail various forms of mobilities across national borders. Protesters often draw inspiration from protests elsewhere, re-appropriating their symbols and their tactics (Chabot \& Duyvendak, 2002). While protest visuals can travel fast, spurring transnational mobilization or becoming seemingly global icons (Chabot \& Duyvendak, 2002; Mattoni \& Teune, 2014; Mortensen, 2017; Mortensen \& Trenz, 2016), less attention has been devoted to their adaptation to local contexts (for an exception, see Olesen, 2014). In particular, questions still remain on which transnational cultural references are taken up in national protest, how they become implicated in the local production of contention, and what the ideological implications of their use are.

The transnational circulation of cultural references is conceptualized here with the help of broader discussions of hybridity, glocalization, flows, and de/reterritorialization. From a sociological perspective, the merger of cultural resources anchored in different local contexts can be understood as a form of glocalization (Robertson, 2012). The blending of the local and the global (or glocalization) draws attention to how seemingly global ideas or expressions are localized, leading to the creation of new cultural resources (Roudometof, 2016). Glocalization is a dialectical process, signaling the increased interconnectedness of localities. Yet, glocalization may also unwittingly universalize and standardize an essentialist understanding of locality as synonymous with nationally bounded cultures (Robertson, 2012). Furthermore, the term "global" hides more than it explains. The circulation of cultural resources often follows from historical (e.g., colonialism) and recent hierarchies (e.g., transnational corporations), suggesting the "global" is partial and contextual, better understood as a "locally instigated wave [that] spreads throughout the globe or close to it" that is refracted at the local level, resulting in a plethora of glocalized cultural products (Roudometof, 2016, p. 388).

Similarly, hybridity refers to the "fusion of two hitherto relatively distinct forms, styles, or identities, crosscultural contact, which often occurs across national borders as well as across cultural boundaries" (Kraidy, 2005, p. 5). Drawing from the traditions of international and intercultural communication, hybridity destabilizes the very notions local/global by challenging the view of culture as static and territorially bounded. Instead, the historical circulation of signs and meanings is brought to the fore, suggesting contemporary mixing processes are different today only in accelerating the normalization of hybridity as a sociocultural phenomenon (Kraidy, 2005). Neither progressive nor subversive in itself, hybridity can stimulate critical thinking, particularly in relation to nationalism and ethnic exclusivism - although it does not necessarily unsettle them (Anthias, 1999; Thomas, 1998). Like glocalization, hybridity can also bear the traces of historical and contemporary hierarchies. Thus, hybrid texts may reflect colonial histories (Piot, 2001) or privilege some national cultural resources over others (Anthias, 1999). Furthermore, hybridity favors social actors "with the means to translate and name the world, while weakening the agency of other participants....The means and ability to communicate are therefore an important determinant of agency in intercultural relations that form the crucible of hybridity" (Kraidy, 2005, p. 152). Local social actors engaged in the production of hybridized texts often draw on their own external networks, which may reflect specific forms of cultural capital; as such, they are consequential to which external cultural resources are brought in and which local cultural resources are selected for the mixing process. In that sense, "the local is at once a site of empowerment and marginalization" (Kraidy, 2005, p. 155).

The normalization of hybridity remains an uneven process, simultaneously celebrated and resisted as it inevitably unsettles moral and material universes. The various mobilities (flows) characterizing contemporary societies (goods, money, people, technologies, media, images, and ideas) compound this unevenness, as each circulates in irregular ways that often remain tributary to the "historical, linguistic, and political situatedness of different sorts of actors" (Appadurai, 1996, p. 33). Under the impetus of pervasive mediatization, these mobilities also generate "non-places" (Augé, 1993, as cited in Tomlinson, 1999, pp. 108-113) and "culturally odourless" resources (Iwabuchi, 2002) that do not bear-at least in an immediate way-clear connections to nationally-defined cultures. This can enhance their circulation, spurring new forms of "cultural proximity" (Iwabuchi, 2002), but it can also enable new forms of agency and ownership rooted in a search for the "authenticity" of the local.

The ability to tap into transnational cultural repertoires has been celebrated as an expression of cosmopolitanism-that is, an outlook on the world rooted in openness towards different cultures and in a sense of global interconnectedness and moral responsibility. It can also be read as a struggle between structural dominance and individual agency (Kraidy, 2005), a strategic choice (Skey, 2012), or an expression of (transcultural) class affinities (Pieterse, 2015). The 2017 anti-corruption protests in Romania provide an opportunity to further capture the multifaceted struggle over visibility, legitimacy, and power entailed in the re-appropriation of transnational cultural repertoires in contemporary protest cultures.

\section{Analyzing Protest Signs}

This study has analyzed a set of 58 photographs of different protest signs used during the first wave of protests (January 31-February 15, 2017). This set was constructed by collecting photographs of protests from online archives assembled by local bloggers and news media (e.g., https://www.lozinici.ro, http://www.ziare.com, and http://www.artofprotest.ro) 
and from Instagram, by harvesting images posted with one of the popular hashtags during these events (e.g., \#altaintrebare, \#coruptiaucide, \#neamsaturat, \#romaniatrezeste, \#romaniainstrada). While these sources do not capture the totality of protest signs (something that would be, in fact, impossible), they constitute a reasonable record of protest visuals, including diverse protest times, locations, and vantagepoints from where photographs were taken. Photos displaying legible protest signs containing a transnational cultural reference were retrieved and analyzed. Duplicates or minor format/message variations were excluded.

This study is part of a bigger project that has included my participation as an observer in a protest organized by the Romanian diaspora in the Netherlands, followed by fieldwork in summer 2018 in Romania. Having cultural and linguistic competencies was central to recognizing cultural references that, at the time of the protest, counted as "transnational". Such competencies are crucial, as "foreign" cultural references or the hybrids they may lose their "foreignness" with time (Pieterse, 2015, p. 95). I have also interviewed 30 individuals actively engaged in protest mobilization across the country and had several informal discussions with civil society representatives and faculty members. While this fieldwork is not reported here, its insights inevitably informed the analysis and interpretation process. Where possible, I signal this in the reporting of the findings or discussion.

Given the lack of research on home-made protest signs and the specific interest in the meaning-making role of transcultural cultural references, I took an exploratory approach tailoring the analysis process to the two research questions. I started by identifying the context of origin and the domain of reference used (e.g., politics, popular culture texts, etc.). Drawing from multimodal discourse analysis (Machin \& Mayr, 2012), I paid attention to the use of transnational cultural references to craft a political message, guided by questions such as:

- Which aspects of the original context of the reference were retained in the process? For instance, one protest sign re-used the title of the novel The Catcher in the Rye to play a pun upon the Romanian translation of the word "the catcher", while another invoked The Animal Farm's storyline to compare the government to the authoritarian regime described in the book.

- What type of knowledge was needed to recognize the reference?

- Was there a possible and plausible connection between the choice of reference and the broader Romanian political imaginary?

- How was the reference used to make a statement about local politics (people or events)?

- Which aesthetics and stylistic aspects of the protest signs (e.g., figures of speech, rhyme, format of text or illustration) were used?

\section{The Meaning-Making Work of Transnational Cultural References in Protest Signs}

Five categories of transnational cultural references were used across the protest signs analyzed here.

First, political references included past and present leaders, slogans, and events. Unsurprisingly given the cause, placards evoked well-known authoritarian leaders such as Stalin, Hitler, or Mao Zedong. Other iconic political references were tied to either American (Barack Obama's electoral red/blue poster and Donald Trump's [in]famous quotes) or French politics (Louis XIV's quote "L'etat c'est moi" [I am the state], the slogan of the French revolution, and the slogan of the public response to the Charlie Hebdo attacks, "Je suis Charlie").

Second, even though computer culture has become an everyday practice in Romania (although digital divides remain important), the references discussed here have not been produced in Romania. Popular games (Pokémon and Pacman), websites (PornHub), and technology companies (Google) provided material to create localized political messages, alongside references to computer and internet symbols such as right-click, hashtags, emojis, meme templates, and terms of use.

Third, high and popular culture were a preferred reservoir of transnational references for framing the identity and cause of the protests (Milner, 2013; Rovisco, 2017). Posters drew from classical paintings (Da Vinci's Last Supper and Matsys' The Ugly Duchess) and books (Salinger's The Catcher in the Rye, Orwell's Animal Farm, and Shakespeare's Hamlet), song lyrics (Muse's Uprising and The Police's Every Breath You Take), and films/TV series (Star Wars, Star Trek, Game of Thrones, Lord of the Rings, Captain America, Batman, Robin Hood, Pinocchio, No Country for Old Men, Spiderman, Orange is the New Black). US actor Chuck Norris, a classical Hitchcockian image of scared female eyes, and the "Wanted" poster aesthetic popularized by Western films were also used. A few placards were created out of meme templates based on superhero films-Batman slapping Robin and Dr. Octopus, while some protesters cosplayed science fiction or superhero film characters.

Fourth, culture jams of brands played upon the slogans or logos of multi-national corporations such as Coca-Cola, Nokia, Nike, and Victoria's Secret, along with Philip Morris' cigarette brand Marlboro. They were less common across the data set. While culture jamming's subversive ethos can fulfill an anti-capitalist critique in protest (Romanos, 2013), in this case it had a primarily humorous function.

The final category included iconic symbols (slogans, objects, and gestures) such as the feminist "We Can Do It!" poster or the motivational "Keep Calm and Carry On" poster, the Guy Fawkes (Anonymous) mask, and the raised clenched fist.

These references illustrate the Romanian middleclass' desired "cultural proximity" (Iwabuchi, 2002) with the West (Gubernat \& Rammlet, 2021; Kiss \& Székely, 
2021). The classical Western canon (e.g., Da Vinci or Shakespeare), but also popular films, songs, culture jams, or computer culture speak not just of the mobility of texts, but also of their usefulness for legitimizing the local as Western. While such references remain recognizable across different socioeconomic classes, they are normalized primarily among the professional, white-collar groups that have been instrumental to the (digital) mobilization in the 2017 anti-corruption protests. This reading was strengthened during my fieldwork, as interviewees explained their vision of political governance as informed by the allegedly objective organizational efficiency of the multi-national corporation. Most of them were young professionals or local entrepreneurs, who had often travelled extensively or had established transnational business ties. Their grassroots digital leadership (Bakardjieva et al., 2018) was enabled by their ability to strategically and professionally deploy information and communication technologies in protest (e.g., one citizen collective proudly called itself "Geeks for Democracy").

The use of such cultural references can then be reasonably read as strategic in the sense of participating in the struggle between empowerment and marginalization unfolding at the local and regional levels (Kraidy, 2005). Historically, Romanian elites have looked towards "foreign role models" to clear the country's reputation of the often negative "Balkan" or "Eastern" labels circulated in the West (Gallagher, 1997). Within the regional dichotomy East/West, the grassroots use of the Western cultural pool performs protesters as "true" Westerners. Such cultural references, then, help protesters cast their political claims as a fight between the "civilized", pro-Western people and the "backward" strata lacking "all the attitudinal and cultural requisites of a 'normal" (meaning modern, developed, and Western-like) society" (Kiss \& Székely, 2021, p. 8; see also Abăseacă, 2018; Gubernat \& Rammelt, 2021).

\subsection{The Semantic Usefulness of Recognizability}

One use of the transnational cultural references in the production of glocal protest communication relies on their iconicity to draw attention to the protest cause (Bartmanski, 2015). Where their original moral and political meanings are silenced, their recognizability is strategically re-appropriated as an attention-grabber. This was the case of several references to then-newly elected US president Donald Trump. One placard, for instance, replaced America in Trump's electoral slogan "Make America great again" with the names of Romanian prisons such as Jilava (the prison for political dissenters during communism) and Rahova (a maximum-security prison for men). The resulting message targeted the political opponent: The idea of making prisons "great again" directly engaged with the protesters' requests to repeal the extraordinary ordinance OUG13 and to punish corruption. By putting corrupt politicians in jail, prisons would be "great again." Like many other signs-whether using transnational cultural references or not-this one was written in English. While this preserved the integrity of the original reference and its iconic appeal, it also signaled an allegedly mundane integration of English into the Romanian protest landscape.

Another placard used the mobilization slogan against the Charlie Hebdo attacks, "Je suis Charlie." In its original context, the slogan conveyed a moral and political position: "Either you are in favour of free speech and the right to offend or you are against" (Klug, 2016, p. 223). In the 2017 anti-corruption protests, this moral and political meaning was erased, preserving only its formulation in French (which presumably enhanced its recognizability as an iconic slogan). One poster collaged printed photographs of politicians seen by protesters as corrupt. Under each photograph, the author had written: "Je suis plagiator. Je suis jefuitor. Je suis praduitor. Je suis informator. Je suis prostul lor. Je suis infractor" [I am someone who commits plagiarism. I am a robber. I am a thief. I am an informant. I am their fool. I am a criminal]. In the middle of the collage, the photograph of the first post-communist president with a photo-edited crown and the caption "Je suis tatal lor" [I am their father]. Understanding this chain of signification requires historical awareness of the political debates in post-communist Romania. Minimal understanding of French may be needed for understanding, although the iconic status of the slogan may ensure its translation has become common knowledge. Furthermore, the placard becomes funny through the rhyme of the chosen Romanian words (all ending in "-or") and through the confessional frame brought along by the French phrase "I am X." While some of these confessions refer to criminal deeds, two stand out and further contribute to the comic effect: one seemingly admits he is not even a criminal but merely the others' fool; the other introduces former Romanian president Ion Iliescu (also a founder and former president of PSD), made to confess "fathering" all these forms of criminality and ultimately corruption. Illustrating what Abăseacă $(2018$, p. 681) calls the "unresolved issues of the past," this protest sign historicizes corruption as a consequence of communism perpetuated by unfit political elites.

\subsection{The Value of Generic Interpretive Frames}

Other transnational cultural references, while still widely recognizable, were used primarily for their generic meanings, helping placard authors craft new political messages. Such references provide over-arching yet simplistic interpretive frames adapted to highlight the immorality of the local governing class. This is the case of photo-edited posters cropping the face of the PSD leader Liviu Dragnea onto well-known portraits of Stalin, Kim Jung-un, Mao, or Hitler. In most cases observed across the sample, meaning-making was achieved merely by juxtaposing the Romanian to the transnational political figures. The latter were signified via iconic signs: the 
hairdo and black costumes of the North Korean president, the Nazi uniform with the swastika armband, or the propagandistic portrait of Stalin in uniform. Such posters invite a reading of the PSD leader through the generic interpretive frames associated with the other political figures, such as their ruthless and totalitarian rule. Carrying such a poster to protest is also performative, signifying citizen power in drawing politicians accountable. Indeed, one of the most widely circulated slogans during the protests was "We see you": While a reference to the importance of citizen accountability in democracy, the protests themselves publicly embodied this political value.

Film characters and titles constituted a second example of transnational cultural references used for their generic political and moral connotations. With its overarching frame of the battle between good and evil, the Star Wars filmic universe has been a transnational staple of protest (Gray, 2012). In the Romanian protests, one poster edited Dragnea's face onto an image of the Emperor clad in a hooded dark robe, readying his arms to use the force against his opponents. The poster also included textual elements: "Emperor Dragnea," "Darth Corrupt," and "PSD Strikes Back" - all in English. In this case, the generic framing of the Star Wars character as an evil ruler served to anchor Dragnea's own character. Yet, the connotation of such fictional tyranny is not only political illegitimacy, but also its inevitable failure-as the forces of good eventually prevail. Thus, the poster implicitly announced the powerful politician's impending doom (something magnified by the presence of the poster within a citizen protest against the government). Indeed, the frame of resistance-where individuals succeed, against all odds, defeating a totalitarian and powerful regime-has emerged transnationally in protest (McClelland-Cohen \& Endacott, 2020, p. 850). In the Romanian context, the hashtag of the protests (\#rezist) bears a striking-yet probably unrelated (according to my participants)-resemblance to the use of \#resist or \#TheResistance circulated in the anti-Trump and the antiBrexit movements (Monteverde \& McCollum, 2020).

\subsection{The Ludic Appeal}

The placards' mixing of transnational cultural references with the local protest cause also constituted playful expressions of "vernacular creativity." While this can work in tandem with the other two meaning-making functions above, it can be analytically distinguished as a separate quality of the hybridization process. This quality has to do with the unexpectedly creative and often humorous articulation of meaning. Unexpectedness depends on the viewer's familiarity with protest signs, remaining an interpretive and partial gesture. Yet, to the protest participant seeing dozens or perhaps hundreds of posters a night; or to the researcher perusing thousands of photographs, the "unexpected" emerges inductively from lived experience or the data.
Unexpectedness was generated through the use of transnational cultural references not associated with recent popular cultural texts. If superheroes and science fiction characters spoke to the increasing popularity of these genres over the last decade, Erol Flynn's 1938 depiction of Robin Hood, Chuck Norris' martial arts film characters, or Shakespeare's Hamlet belonged to past cultural flows. This was even more surprising given the protests were largely associated with the young and urban middleclass who might not have been familiar with them. For instance, a beloved 1990s actor of then-fashionable martial arts films and series, Chuck Norris' popularity in Romania had been tied to the introduction of the VCR and the diversification of commercial television stations. One poster written in English read: "Chuck Norris, please help!" invoking the (past) cultural significance of the actor. At the time of being photographed, the placard was carried by a child, enhancing its humorous appeal. While the reference to Chuck Norris builds on his connotation as a punisher of evil characters, other types of (super)heroes are more popular today. In this case, knowledge of past transcultural texts that have marked the local context is needed to understand the poster.

Unexpectedness was also generated by the use of transnational cultural references that did not seem to speak about politics. This was the case of a placard comparing Dragnea to Lord of the Rings' Gollum. Where the pairs Dragnea/Stalin or Dragnea/the Emperor (Star Wars universe) built on the image of evil rulers, his relationship to Gollum was less intuitive at first. The comparison becomes meaningful when Gollum is read as a symbol of the nefarious consequences of lust for power. The poster edited Dragnea's face on a handcuffed Gollum, while the Parliament building was added to the background. The title of the poster read: "Lord of the Scums." Portraying Dragnea as a bold (albeit still donning his iconic moustache), naked, and generally hideous character; handcuffing and labelling him as the "Lord of the Scums" added a humorous layer that both conveyed the shared protest cause and discursively subverted the political leader's power. In another poster, Dragnea's face was pasted onto Erol Flynn's iconic portrayal of Robin Hood, captioned: "Robbing Hood." This association was also not directly intuitive, as Robin Hood's character is a symbol of the poor stealing from the rich-where here it is use the other way around. Written in English, the gerund form of the verb "to rob" was anchored by the visual of Dragnea to signal the idea of politicians stealing from the state. Both cases require more than a basic knowledge of English to appreciate the posters' political message. Yet, English or knowledge of the cultural text was not enough, as understanding the message also required knowledge of the local political context.

\section{Conclusions}

This study examined the meaning-making work of transnational cultural references in protest using the 
case of the 2017 \#rezist protests in Romania. The analysis revealed five types of references providing semantic material for the glocalization of protest communication: political leaders and events, computer culture, high and popular culture, culture jams, and other iconic symbols. Three dimensions of transnational cultural references facilitate their localization. First, such resources were used because of their assumed recognizability among protesters. Their concise, slogan-like style was re-appropriated while their original political or moral meaning was silenced. Second, transnational cultural references provided generic interpretive frames to craft local political messages (with the added benefit of potentially generating transnational visibility). Third, their ludic appeal mobilized "vernacular creativity," commanding attention through their unexpectedness and fusing not only the local and the "foreign," but also different genres and texts. While these dimensions often co-exist within the same protest sign, analytically distinguishing them systematizes the analysis of the transnational dimension of protest communication.

It is tempting to read the use of transnational cultural references as an expression of banal cosmopolitanism (Skey, 2012; Szerszynski \& Urry, 2002) or as a normalization of hybridity (Kraidy, 2005) in protest communication. In the case examined here, the references used in protest communication originated in the Western world. Their use constructs protesters as aligned withand thus, part of-Western cultural consumption and political practices. This is not accidental, as it reflects the political ambition of the Romanian middle-class, seeking to separate itself from corruption (and, by extension, from the communist legacy) and to position itself as the voice of Western democratization/modernization. Indeed, recent analyses have shown how the anti-corruption discourse in Romania draws its legitimacy from "the widening rift between the ideology of 'new Romania' and that of 'old Romania', based on the dichotomy between 'Westernizers' and 'autochthonists' " (Gubernat \& Rammelt, 2021, p. 260; see also Kiss \& Székely, 2021).

The article thus shows that, as with other forms of cultural hybridity, the transnationalization of protest communication remains permeated by and further implicated in the re-construction of (local) hierarchies and claims to power (Kraidy, 2005, p. 156). The use of transnational cultural resources here is thus not merely an expression of the imagined "cultural proximity" between protesters and the original contexts making these resources iconic, but also a political performance making both regional and local claims to power. In addition to their iconicity, generic frames, or creative potential, the selection and use of transnational cultural resources is political, allowing protesters to construct the young, urban, and professional middle-class as the site of progress and democratization. In turn, their use also normalizes the West as the local "global."

The ability to creatively localize "foreign" cultural resources has become a crucial skill in protest com- munication. Even though many transnational cultural resources are recognizable across social strata, in the Romanian context, the young and urban middle-class are more adept at fusing foreign languages (English and French), computer culture and foreign politics with local politics by virtue of their access to resources, including multiple mobility flows. In that sense, hybridization favors them (Kraidy, 2005). In turn, they are likely to select resources that resonate with them and thus express transnational class affinities (Pieterse, 2015, p. 87). Considerations of the transnational dimension of protest communication need to critically engage with the socioeconomic divisions reproduced in and through hybridization processes. While hybridization can amplify the visibility of local protest and facilitate transnational ties among protesters, it can also alienate other (local) socio-economic groups. Thus, in addition to the meaning-making functions afforded by transnational cultural resources, the local politics of their selection remain important in understanding their inclusionary/exclusionary potential.

Finally, the contribution of some of these transnational cultural references to the blurring of the boundaries between online and offline protest space requires a brief note (De Luca et al., 2012; Milner, 2013). On the one hand, meme templates and the deep-fakes start online. They speak to how the production of these protest signs begins at home, drawing inspiration from the digital space in multiple ways. Some of these protest signs were shared as templates on social media, with followers urged to download and bring them-whether personalized or not-to the protest. Others used protest slogans or objects that circulate from one protest site to another. On the other hand, references to computer culture are brought to the streets to incriminate politicians and their actions. For instance, in the Romanian protests, a citizen brought along a printout of the pile of poo emoji. The poster was carefully constructed: It was wrapped in yellow tape and had a long stick enabling it to be raised above the crowds. Such do-it-yourself projects appeal to both participants and scholars as subversive and empowering tokens of "vernacular creativity." Yet, the blending of computer culture with street protest does not signal only the "panmediated" nature of contemporary protests (De Luca et al., 2012), but also a collective imaginary of activism where digital technologies appear as seemingly universal spaces and tools for grassroots political engagement. The inclusions/exclusions of this imaginary of digital activism deserve further scholarly attention.

\section{Conflict of Interests}

The author declares no conflict of interests.

\section{Supplementary Material}

The data set behind this article is available in the EUR Data Repository, https://doi.org/10.25397/eur.14778669 


\section{References}

Abăseacă, R. (2018). Collective memory and social movements in times of crisis: The case of Romania. Nationalities Papers, 46(4), 671-684. https://doi.org/ 10.1080/00905992.2017.1379007

Anthias, F. (1999). Beyond unities of identity in high modernity. Identities, 6(1), 121-144. https://doi.org/ 10.1080/1070289X.1999.9962638

Appadurai, A. (1996). Modernity at large: Cultural dimensions of globalization. University of Minnesota Press.

Bakardjieva, M., Felt, M., \& Dumitrica, D. (2018). The mediatization of leadership: Grassroots digital facilitators as organic intellectuals, sociometric stars, and caretakers. Information, Communication \& Society, 21(6), 899-914. https://doi.org/10.1080/1369118X. 2018.1434556

Bartmanski, D. (2015). Modes of seeing, or, iconicity as explanatory notion: Cultural research and criticism after the iconic turn in social sciences. Sociologica, 1, 1-34. https://doi.org/10.2383/80392

Burgess, J. (2006). Hearing ordinary voices: Cultural studies, vernacular creativity, and digital storytelling. Continuum: Journal of Media and Culture Studies, 20(2), 201-214.

Casas, A., \& Williams, N. W. (2019). Images that matter: Online protests and the mobilizing role of pictures. Political Research Quarterly, 72(2), 360-375. https://doi.org/10.1177/1065912918786805

Chabot, S., \& Duyvendak, J. (2002). Globalization and transnational diffusion between social movements: Reconceptualizing the dissemination of the gandhian repertoire and the "coming out" routine. Theory and Society, 31(6), 697-740.

della Porta, D., \& Kriesi, H. (1999). Social movements in a globalizing world: An introduction. In D. della Porta, H. Kriesi, \& D. Rucht (Eds.), Social movements in a globalizing world (pp. 3-22). St. Martin's Press.

della Porta, D., \& Mattoni, A. (2014). Patterns of diffusion and the transnational dimension of protest in the movements of the crisis: An introduction. In D. della Porta \& A. Mattoni (Eds.), Spreading protest: Social movements in times of crisis (pp. 1-18). ECPR Press.

De Luca, K. M., Lawson, S., \& Sun, Y. (2012). Occupy Wall Street on the public screens of social media: The many framings of the birth of a protest movement. Communication, Culture \& Critique, 5, 483-509. https://doi.org/10.1111/j.1753-9137.2012.01141.x

Faulkner, S. (2013). Images and demonstrations in the Occupied West Bank. JOMEC Journal, 4, 1-19. http:// doi.org/10.18573/j.2013.10254

Gallagher, T. (1997). To be or not to be Balkan: Romania's quest for self-definition. Daedalus, 126(3), 63-83.

Gori, F. (2016). What is an image? W. J. T. Mitchell's picturing theory. In K. Purgar (Ed.), W.J.T. Mitchell's image theory: Living pictures (1st ed., pp. 40-60). Routledge.

Graham, T., \& Hajru, A. (2011). Reality TV as a trigger of everyday political talk in the net-based public sphere. European Journal of Communication, 26(1), 18-32. https://doi.org/10.1177/0267323110394858

Gray, J. (2012). Of snowspeeders and imperial walkers: Fannish play at the Wisconsin protests. Transformative Works and Cultures, 10. https://doi.org/10.3983/ twc.2012.0353

Gubernat, R., \& Rammelt, H. P. (2021). "Vrem o ţară ca afară!": How contention in Romania redefines state-building through a pro-European discourse. East European Politics and Societies, 35(1), 247-268. https://doi.org/10.1177/0888325419897987

Hariman, R., \& Lucaites, J. (2002). Performing civic identity: The iconic photograph of the flag raising on Iwo Jima. Quarterly Journal of Speech, 88(4), 363-392.

Hubbert, J. (2014). Appropriating iconicity: Why Tank Man still matters. Visual Anthropology Review, 30, 114-126. https://doi.org/10.1111/var.12042

Iwabuchi, K. (2002). Recentering globalization: Popular culture and Japanese transnationalism. Duke University Press.

Juris, J. S. (2008). Performing politics: Image, embodiment, and affective solidarity during anti-corporate globalization protests. Ethnography, 9(1), 61-97. https://doi.org/10.1177/1466138108088949

Kiss, T., \& Székely, I. G. (2021). Populism on the semiperiphery: Some considerations for understanding the anti-corruption discourse in Romania. Problems of Post-Communism. Advance online publication. https://doi.org/10.1080/10758216.2020.1869907

Klug, B. (2016). In the heat of the moment: Bringing "Je suis Charlie" into focus. French Cultural Studies, 27(3), 223-232. https://doi.org/10.1177/ 0957155816648105

Kraidy, M. (2005). Hybridity, or the cultural logic of globalization. Temple University Press.

Machin, D., \& Mayr, A. (2012). How to do Critical Discourse Analysis. SAGE.

Mattoni, A., \& Teune, S. (2014). Visions of protest: A media-historic perspective on images in social movements. Sociology Compass, 8(6), 876-887.

McClelland-Cohen, A., \& Endacott, C. G. (2020). The signs of our discontent: Framing collective identity at the women's march on Washington. Communication Studies, 71(5), 842-856. https://doi.org/ 10.1080/10510974.2020.1784246

McCurdy, P. (2012). Social movements, protest and mainstream media. Sociology Compass, 6(3), 244-255. https://doi.org/10.1111/j.1751-9020.2011.00448.x

Mercea, D. (2020). Tying transnational activism to national protest: Facebook event pages in the 2017 Romanian \#rezist demonstrations. New Media \& Society. Advance online publication. https://doi.org/ 10.1177/1461444820975725

Milner, R. (2013). Pop polyvocality: Internet memes, 
public participation, and the Occupy Wall Street movement. International Journal of Communication, 7, 2357-2390. https://ijoc.org/index.php/ijoc/ article/view/1949/1015

Monteverde, G., \& McCollum, V. (2020). Introduction. In G. Monteverde \& V. McCollum (Eds.), RESIST! Protest media and popular culture in the Brexit-Trump era (pp. 1-16). Rowan \& Littlefield.

Mortensen, M. (2016). "The image speaks for itself" - or does it? Instant news icons, impromptu publics, and the 2015 European "Refugee Crisis". Communication and the Public, 1(4), 409-422.

Mortensen, M. (2017). Constructing, confirming, and contesting icons: The Alan Kurdi imagery appropriated by \#humanitywashedashore, $\mathrm{Ai}$ Weiwei, and Charlie Hebdo. Media, Culture \& Society, 39(8), 1142-1161. https://doi.org/10.1177/ 0163443717725572

Mortensen, M., \& Trenz, H.-G. (2016). Media morality and visual icons in the age of social media: Alan Kurdi and the emergence of an impromptu public of moral spectatorship. Javnost-The Public, 23(4), 343-362.

Olesen, T. (2014). Dramatic diffusion and meaning adaptation: The case of Neda. In D. Della Porta \& A. Mattoni (Eds.), Spreading protest: Social movements in times of crisis (pp. 71-90). ECPR Press.

Olteanu, T., \& Beyerle, S. (2017). The Romanian people versus corruption. The paradoxical nexus of protest and adaptation. Partecipazione e Conflitto, 10(3), 797-825.

Parry, K. (2015). Visibility and visualities: "Ways of seeing" politics in the digital media environment. In S. Coleman \& D. Freelon (Eds.), Handbook of digital politics (pp. 417-432). Edward Elgar.

Philipps, A. (2012). Visual protest material as empirical data. Visual Communication, 11(1), 3-21. https://doi. org/10.1177/1470357211424675

Pieterse, J. N. (2015). Globalization \& culture: Global mélange (3rd edition). Rowman \& Littlefield.

Piot, C. (2001). Of hybridity, modernity, and their malcontents. Interventions, 3(1), 85-91, https://doi.org/ $10.1080 / 13698010020027047$

Poell, T. (2014). Social media and the transformation of activist communication: Exploring the social media ecology of the 2010 Toronto G20 protests. Information, Communication \& Society, 17(6), 716-731.

Robertson, R. (2012). Globalisation or glocalisation? Journal of International Communication, 18(2), 191-208.

Romanos, G. (2013). Humor in the streets: The Spanish Indignados. Perspectives on Europe, 43(2), 15-20. https://eprints.ucm.es/id/eprint/30537/1/Romanos \%202013\%20POE\%20Humor\%20in\%20the\%20 Streets\%20-\%20The\%20Spanish\%20Indignados.pdf

Roudometof, V. (2016). Theorizing glocalization: Three interpretations. European Journal of Social Theory, 19(3), 391-408. https://doi.org/10.1177/13684310 15605443

Rovisco, M. (2017). The Indignados social movement and the image of the occupied square: The making of a global icon. Visual Communication, 16(3), 337-359.

Rovisco, M., \& Veneti, A. (2017). Picturing protest: Visuality, visibility and the public sphere. Visual Communication, 16(3), 271-277.

Skey, M. (2012). We need to talk about cosmopolitanism: The challenge of studying openness towards other people. Cultural Sociology, 6(4), 471-487. https:// doi.org/10.1177/1749975512445434

Szerszynski, B., \& Urry, J. (2002). Cultures of cosmopolitanism. The Sociological Review, 50(4), 455-481. https://doi.org/10.1177/003802610205000401

Thomas, N. (1998). Hybrid histories: Gordon Bennett's critique of purity. Communal/Plural, 6(1), 107-116.

Tomlinson, J. (1999). Globalization and culture. Polity Press.

van Leeuwen, T. (2011). Semiotics and iconography. In T. van Leeuwen \& C. Jewitt (Eds.), The handbook of visual analysis (pp. 92-118). SAGE. http://dx.doi.org/ $10.4135 / 9780857020062$

Vanni, I. (2007). How to do things with words and images: Gli Imbattibili. In M. Stocchetti \& J. SumaliaSappanen (Eds.), Images and communities: The visual construction of the social (pp. 147-170). University of Helsinki Press.

Wetzstein, I. (2017). The visual discourse of protest movements on Twitter: The case of Hong Kong 2014. Media and Communication, 5(4), 26-36. http://dx. doi.org/10.17645/mac.v5i4.1020

\section{About the Author}

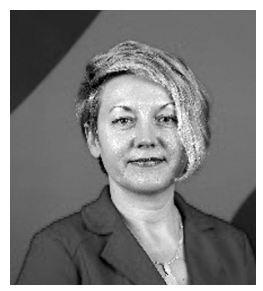

Delia Dumitrica (PhD) is Associate Professor in Political Communication in the Media \& Communication program at Erasmus University Rotterdam. Her research focuses on digital activism; the discursive construction of new media; and everyday forms of nationalism. Her work has appeared in various book chapters and journals such as Information, Communication \& Technology; The International Journal of Communication; Media, Culture \& Society; and Nations \& Nationalism. 